\title{
Student Organizations as Historical Actors: The Case of Mass Student Aid
}

\section{NIGEL R. MOSES}

Brock University

\section{ABSTRACT}

The National Federation of Canadian University Students (NFCUS) and the Canadian Union of Students (CUS) had historicity; that is, they helped transform the field of historical action by convincing business, government, university administrators and public opinion on the need for mass student-aid programs and low tuition fees. From the 1950 s to the mid-1960s, NFCUS and CUS campaigned for government-funded mass student-aid; in fact, it was their number one "national affairs" concern. Governments responded to the NFCUS and CUS accessibility lobby with the Canada Student Loan Program (CSLP) in 1964, the Ontario Student Assistance Plan (OSAP) in 1966 and "frozen" tuition fees by 1967. The achievement of the CSLP divided Quebec and EnglishCanadian students and began a process of removing traditional student movement catalysts. NFCUS's and CUS's lobby for non-repayable student bursaries was co-opted. However, the level of accessibility to postsecondary education was unprecedented and, in part, provided the social conditions for the emergence of new social movements. 


\section{RÉSUMÉ}

La Fédération nationale des étudiants universitaires canadiens (FNEUC) et la Fédération canadienne des étudiants (FCE) avaient de l'historicité, c'est-à-dire qu'elles participèrent dans la transformation du champ d'action historique en convainquant le monde des affaires, les gouvernements, les administrateurs d'universités et l'opinion publique qu'une diminution dans les frais de scolarité et une augmentation dans les bourses pour les étudiants étaient des besoins réels. A partir des années 1950 jusqu'au milieu des années 1960, la FNEUC et la FCE travaillèrent pour une augmentation de l'assistance aux étudiants et aux étudiantes par les différents niveaux de gouvernement; en effet, c'était leur première préoccupation dans les affaires nationales. Les gouvernements canadien et ontarien répondirent aux demandes de la FNEUC et de la FCE avec la création du Programme canadien de prêts aux étudiants (PCPE) en 1964 et du Régime d'aide financière aux étudiants de l'Ontario (RAFEO) en 1966 ainsi qu'avec un engagement de fixer les frais de scolarité en 1967. La réussite de la PCPE occasionna une division entre les corps étudiants québécois et canadien anglais, précipitant un processus de disparition des catalyseurs traditionnels du mouvement étudiant. La poussée de la FNEUC et de la FCE >pour la création de bourses sans restitution fut saboté. Néanmoins, le niveau d'accessibilité aux études postsecondaires était sans précédent, et contribua aux conditions sociales favorables à l'apparition de nouveaux mouvements sociaux.

\section{INTRODUCTION}

In this paper, I discuss the results of my research on the National Federation of Canadian University Students (NFCUS) and the Canadian Union of Students (CUS) in the 1950s and 1960s. With particular attention to Ontario, I focus on NFCUS and (early) CUS between the years 1955 to 1966 . I examine briefs presented to state agents such as politicians, university administrators and various commissions, and most importantly, how state agents responded to these briefs. I also examine the opinions of former student leaders. 
My main argument is that student activism led to increased university accessibility and this, in turn, helped form the field of historical action or policy environment for the next half century. The availability of student loans and bursaries can be considered a type of state co-optation that had mixed results. When I use the term "co-optation" here, I do not mean in zero-sum terms, as simply "co-optation by the state" where all opposition is demobilized. It is clear, for example, that the availability of student-aid after the mid-1960s increased accessibility and helped determine student activism in the late 1960s and beyond.

The NFCUS, or simply "NFCUS" (pronounced either with a "nif" sound, or a "nuf," sound) worked on behalf of Canadian university students after it formed in 1927. Student delegates elected from local NFCUS committees and student councils met biannually. During the Second World War, NFCUS stopped operating, but started again immediately after the war to begin its lobby for accessibility. NFCUS leaders became keen participants in international student politics and developed a substantial program of "services," including life insurance, student discounts, student exchanges and national competitions (UWO Gazette, 1955b). NFCUS changed its constitution and name to the Canadian Union of Students (CUS) in 1963 after achieving, momentarily, a French and English student organization that recognized the fundamental bi-nationalism of the Canadian state. This arrangement crumbled a year later.

Around 1968, many student councils reacted negatively to CUS's radicalization. Rather than staying and working within the organization, they sponsored successful withdrawal referenda and effectively destroyed CUS. "Fighting brush fires," as one former NFCUS President called it, was nothing new to national student politics (for example, see Winsor, 1958), only this time the withdrawals all came at once. CUS ceased operations in 1969. Ad hoc national meetings of student councils continued, and in 1972 the National Union of Students (NUS) was formed. NUS changed its name to the Canadian Federation of Students (CFS) in 1981. Today's Canadian Federation of Students (CFS) is therefore part of a long, almost continual tradition of national student organization going back to 1927 . 
In the early to mid-1950s, the public was predominantly opposed to government funding of scholarships and student-aid. This opposition is evident in the negative response to the federal Liberal government's Canada Council scholarship programs that were established in 1956. Granatstein (1986) believes that the Canada Council, despite its strategic importance for developing Canadian scholarship, was a contributing factor in the federal Liberal election defeats of 1957 and 1958. Most voters were appalled that their government would fund such a frivolous enterprise when, according to Granatstein, the needs of veterans and pensioners were generally seen as more important. Sheffield's (1955) university enrolment projections, which suggested that market forces alone would produce high enrolment, was another important factor making student-aid a low priority for most politicians throughout the 1950s.

By the early 1960 s, public opinion had reversed. Support for student-aid was everywhere. As I will show, student activism played a major role in this reversal. NFCUS leaders' willingness to struggle for social justice - albeit from a white, male, heterosexual and able-bodied perspective - was a central reason why the public, university administrators, businessmen and politicians reversed their opinion on mass student-aid in the late 1950s and early 1960s. Jacques Gérin, NFCUS President 1959-60, (personal communication, 1992) typifies the position of national student leaders in the 1950s and early 1960s:

The first and foremost [issue] was more money for education, namely scholarships for students, accessibility to education. We argued for reduced costs. The issue in those days was that university education was for a reserved lot: privileged students who had the means. And that meant only $8 \%$ of the student-aged population was at university. So at all levels provincially, nationally - that was the big fight - to open up university education.

NFCUS members were the most persistent lobbyists on the issue of student-aid, and for a time the only lobbyists. Through its efforts, NFCUS had a profound impact on Canadian society.

NFCUS and CUS leaders were, in part, mediators of class and generation-related conflicts. Young men and women of working class and intermediate strata origins experienced social conflict with the 
bourgeoisie, represented by certain university administrators and politicians of previous generations (see Axelrod, 1982; Barkans \& Pupo, 1978). I do not overly concern myself here with debates over social class relations and politics (see Ehrenreich \& Ehrenreich, 1977, 1978). In the terms of French sociologist Alain Touraine, I attempt instead to describe how a socially subordinate, predominantly middle-stratum, pre-babyboom generation of youth produced changes in social relations and cultural orientations. These relations and orientations are seen most readily in the form and practice of government policy and subsequent form and practice of student politics.

Students in the 1950 s and 1960 s came mostly from a contradictory and expanding middle stratum. They did not constitute a coherent social class, yet they were being groomed to become a new technological and managerial elite. The political form that student organizations took and the political alliances their leaders established, allowed them to play a pivotal role in the determination of welfare state policy. In other words, the younger generation had historicity. This focus on historicity is part of a broader paradigmatic shift underway in sociology, and particularly in the sociology of childhood and youth. According to James and Prout (1997), a focus on children or youth as "active social beings, constructing and creating social relationships" (p. 23) rather than pre-social beings in various stages of development, constitutes part of a "new paradigm." In the next section, I explore this repositioning of young people in social analysis; after that, I discuss my methods. Then I provide a detailed description of the NFCUS and CUS lobby for student-aid.

\section{RECENT LITERATURE ON CANADIAN YOUTH AND STUDENT MOVEMENTS}

Cyril Levitt's (1984) study of Canadian student movements of the "sixties" glossed over important transformative social relations of the 1950s to mid-1960s: the development of "accessibility." While Levitt has added a great deal to our knowledge of Canadian student history, his inattention to students' concern with accessibility, as well as the lasting and significant social effect this had, creates a serious flaw in his analysis of late 1960 s Canadian student politics. Levitt does not 
acknowledge how changes in student-aid programs had a major structuring effect on student organization and the field of historical action. Other examples of student-driven policies that had this structuring effect include the easing of in loco parentis regulations ${ }^{1}$ in the early 1960 s, stable tuition-fee levels established by 1967 , and student representation on university decision-making bodies gained in the late 1960s and early 1970s.

Levitt completely ignores NFCUS. Knowledge of NFCUS and early CUS's prolonged struggle for accessibility and how Canadian state agents responded to this struggle, is crucial for understanding the subsequent development and transformation of Canadian student politics. Kostash (1980) documents the development of Canada's new left - the anti-nuclear and community-organizing movements - of the late 1950s and early 1960 s, but, like Levitt, overlooks the important formative influence of NFCUS. Doug Owram's (1996) recent generation approach to "youth radicalism in the sixties" makes exactly the same mistake as Kostash and Levitt; he is oblivious to NFCUS and the way it changed the historical field of action. The oversights of Kostash, Levitt and Owram are serious, especially in light of my claim that NFCUS historicity is key to understanding subsequent student movements.

For Owram (1996, pp. ix-xi), the influence of the baby boom derives from four main "historical forces:" (1) its relative size; (2) the affluence its members enjoyed; (3) its "link to the turbulent decade" [the 1960s]; and (4) the boomers' "expectations that they would have a special effect." Owram's demographic and economic explanations - the first two "historical forces" - offer nothing original. This position is standard in the much larger U.S. literature. Altbach (1981) being exemplary. What is original, however, is his focus on Canadian youth in the 1945-1970 period. Thus his work partially corrects what Goldson (1997) refers to as relations of "marginalization and exclusion" of children and youth, in this case, in the historical surveys of Canada. Owram, unfortunately, does not develop theoretically or empirically his fourth "historical force," which borders on an agency perspective for its concern with youthful "expectations." Owram, echoing Foot and Stoffman (1996), tends toward demographic reductionism, with the cultural form of late 
1960 s "youth radicalism" being explained mainly as the sheer force of a large and affluent generation. Owram improperly acknowledges youth culture itself as an agent of social change and thus fetters our understanding of the dynamics of contemporary youth-adult and youth-state relations. If Foot and Stoffman are right, that "demographics are two-thirds of everything," then the "other third," so to speak, is human agency.

I agree generally with Owram that an overall "turbulence" had a bearing on 1960s youth movements. However, as he does throughout his work, he makes the common mistake of separating actors from events. Owram states the following, for example: "[The baby boom generation] entered their teens as the emphasis on security and conformity began to wear thin" (p. 315). These youth, in fact, challenged the values of security and conformity; "security" and "conformity" were not a priori social structures that youth "entered." It makes more sense to say youth constituted a movement that resisted security and conformity. Owram inadequately conceptualizes the human subject and the complex ideological dispositions of the 1960s baby-boomers. For this reason, his attempt to extend his historical analysis to understanding contemporary politics and culture is weak.

For Owram, the national student organization before the mid-1960s was a mere "service organization." This is inaccurate. Besides being at the forefront of a persistent accessibility movement, NFCUS leaders were active in both Soviet and C.I.A.-influenced international student organizations, organized national educational "seminars," and discussed how to build a "student movement." Moreover, Owram's belief that Quebec francophones walked out of NFCUS in 1964 because of rising "Quebec separatism" is misleading. As I show below, the situation was far more complicated. Unlike Owram, my analysis of student politics is philosophically and historically linked to the concerns of the new left itself, namely, the co-optation concept, and what or who were the agents of change. Owram's review of the events of the "counter-culture" and "student radicalism" is interesting and empirically valid. Yet it is overly focused on the baby-boom cohort, those, according to Owram, "born between the late war and 1956 or 1956" (p. xiv). NFCUS student leaders of the $1950 \mathrm{~s}$, born in the late 1930 s and early 1940 s — pre-boomers by 
Owram's own definition — had, in part, "prefigured" (W. Breines, 1982) the social relations of late 1960 s youth organizations and movements. It was the relatively small generation of pre-boomers who helped form the conditions of accessibility and inclusion that made late 1960 s student radicalism possible. This fact plays down the importance of cohort size as a determining factor of cultural shift in the late 1960 s, which is a central feature Owram's analysis.

\section{THE THEORETICAL FRAMEWORK: HERBERT MARCUSE AND ALAIN TOURAINE}

The co-optation concept has strong roots in the Marxist tradition, especially in the "polymorphous" Marcusian influences on the new left (see P. Breines, 1970, 1971). Marcuse's One Dimensional Man (1964) and Repressive Tolerance (1965) appeared at a crucial time in the development of North American new left student protest in the 1960s. Marcuse described how consumerism, mass media and liberal social policies were, in fact, co-optive instruments that placated the masses and thwarted all forms of dissent. Such ideas had a powerful effect on many young people who were beginning to reject the conservative values of their parents and to distrust politicians, university administrators and business and military leaders alike. North American students, starved for a critical analysis of their society, were naturally drawn toward Marcuse's views. This is not the place to provide a full account of Marcuse's ideas and especially his profound influence on Canadian student and youth activists of the mid-to late 1960s. However, a radically modified notion of Marcuse's co-optation provides a good departure point for my analysis of student politics.

By the late 1960s and early $1970 \mathrm{~s}$, it appeared that Marcuse was right - dissent had been thwarted and the masses were placated in a "onedimensional" social order. In the wake of the collapse of new left student movements and the rise of the "conservative restoration" (Shor 1986), it appears that the human subject alone was too weak to counter technocratic and anti-democratic tendencies in mass society.

In relation to this essentially Marcusian viewpoint, which reduced the human subject to an all-powerful social order, Bowles and Gintis 
produced their influential Schooling in Capitalist America (1976). Moreover, in most North American departments of sociology, the legacy of Talcot Parsons and functionalism lived on, reinforcing liberalism as the dominant world view. Yet despite these anti-humanist, structureemphasizing theories, there was always an undercurrent of denial; the human subject was, in fact, doing unexpected things. It was inventing language and changing social relations in unanticipated ways, often without any centralized control. The actual activities of people in social movements always seemed at odds with theory. This was certainly the case with Marcuse's mid-1960s theories, which were popularized and disputed by student activists from the time they appeared (for examples, see Harding, 1969, and W. Breines, 1982). People struggled for social justice almost as if they were attempting to show that there was something wrong with the popular Marcusian notions of "establishment" and "selling out." Despite so-called co-optation, it was clear that the university and society had experienced tremendous change. So it is in this so far unnamed and undocumented tradition of battling with the legacy of pessimistic Marcusian theory that this paper is located. One could go further and say that this paper speaks to all such theories that do not place the actor or the subject in a central position in social analysis.

Unlike Marcuse, I take a fluid, multi-dimensional approach to "cooptation." I maintain that social relations of power are not simply reproduced, even though dissent may be reduced temporarily. I see co-optation as a fundamental shift in social relations - with ambiguous winners and losers, not a zero-sum situation with "one-dimensionalism" prevailing. I see the social relations between student organizations and the state as "the material condensation of a relationship of forces" (Poulantzas 1978, p. 152) rather than as Marcuse would have, as a relationship that continually reinforces the status quo through a process of capital-centred integration. So, for example, a Marcusian theorist would view student-aid as just another means for incorporating the subordinate classes into a "one dimensional society." Any dissenting movements claiming that the university is elitist would be easily thwarted, as would be any popular socialist revolt. My analysis is more nuanced. I agree with Marcuse that there is a process of incorporating dissent. However, 
in my view, student-aid produces a variety of revised political alliances and possible socio-cultural outcomes. This will be made clear in my descriptions of historical events. One has to see how social movements of dissent are not simply demobilized and defused. Subordinate social actors can instigate significant changes in state relations that do not necessarily benefit dominant social actors' interests over the long-term. The state and society are viewed less as an unchanging, one-dimensional order that absorbs all forms of dissent, and more as a social relation that is prone to transformation by social movements guided by values and cultural orientations.

For me, co-optation is a social process that describes how government activity and student activism as "institutional forms and social practices" (Jessop, 1982) mediate and mutually determine each other. Both "sides" co-opt each other so to speak, albeit with unequal results. Touraine's $(1988,1995)$ concepts of historicity, cultural orientations and the production of society are useful here. Institutional change occurs in part because of social agency, an example being when Canadian students convinced politicians and university administrators for mass student-aid. To the degree that social relations are transformed according to the interests, values and cultural orientations of a particular agent, that agent is said to have historicity. NFCUS and CUS played a major role in forming a political alliance between subordinate and dominant social agents. Student leaders convinced ruling elites of the benefits of student-aid, which increased accessibility to education and influenced class and other social formations. The social policies that condensed were not exactly what NFCUS was demanding - loans instead of non-repayable grants - because the policies were a mediation of divergent class-related interests. As Axelrod (1982) points out, "democratic and economic benefits" of postsecondary education were virtually indistinguishable (p. 28). The student-aid lobby allowed "those with different interests and competing political persuasions" to come together for the common purpose of expanding the university. Undoubtedly, the fact that certain businessmen, university administrators and federal and provincial politicians actually held the same moral views as students, despite their class and 
generation differences, was an important factor for providing students with the political space to produce themselves.

Student demands stimulated state action, which led to new "policy environments" in which student leaders tried again to rally more support. Over time, student social movement helped produce a class-related institutional shift that helped consolidate the new hegemonic conditions of the welfare state. State power was achieved when the "state as an institutional ensemble" (Jessop, 1982, p. 229) adjusted to student and other personal rights and henceforth conditioned the formation of subsequent social movements. Governments "took students seriously" and thus consolidated their hold on political power. Just as student-aid was provided to veterans in part to diffuse any possibility of a revival of late-1930s style worker radicalism (Brint \& Karabel, 1989), dominant class agents aimed again to defuse a potentially threatening situation while they worked with students in the 1950s to mid-1960s.

During co-optation, the social relations of the state are transformed. This determines the field of historical action, favouring the dominant social force's ability to realize its interests over those of the subordinate social force. But the capability for further action, is not de facto eliminated or totally absorbed, as in pessimistic Marcusian analysis. Instead, co-optation or mutual determination transforms social relations, creating new possibilities and conditions for social intervention.

Student-aid and low tuition fees, of course, were not the only means by which the state controlled, shaped and channeled dissent. The strategic use of accessibility policy should also be seen in relation to the influence of mass media on student movements (see Cohen, 1972; Gitlin, 1980) and to the federal Liberal's volunteer youth corps, the Company of Young Canadians, a group that was created in 1965 and which effectively took control of the Student Union for Peace Action's new left community organizing projects (Daly, 1970). There is also the issue of surveillance (Clearwater, 1998; Kostash, 1980) and infiltration and disruption (Churchill \& Vanderwall, 1990; Stern, 1967).

Student-aid and low tuition fees did not simply undermine NFCUS and CUS, and later, new left student movements. Student-aid and low tuition fees transformed social relations and reorganized hegemony in 
line with capitalist principles and assumptions - but with unpredictable results, even as I write. Despite its serious faults, accessibility policy did help diversify the social composition of student populations throughout the 1960s (Anisef, 1985). In this sense, NFCUS and CUS of the 1950s and mid-1960s can be said to have helped produce the new left student movements of the late 1960s and the various personal rights struggles of the 1970s and beyond. Furthermore, this paper corrects the failure of historians to consider the political role of NFCUS and CUS in the formation of the Canadian welfare state (see, for example, Bothwell, Drummond \& English, 1981; Finkel, 1977; Granatstein, 1986; Guest, 1980).

\section{RESEARCH METHODS}

I looked at past student agency through its various representations: letters and articles in student newspapers, public statements, briefs, reports, commissions, manifestos, citations in the Ontario Legislature, the House of Commons, Cabinet minutes and student protests. I augmented my analysis of student agency by obtaining information through fifteen interviews with former student leaders, mostly presidents of the national organizations and key full-time staff, between 1955 and 1965. I focused on primary sources and interviews because of the practical absence of any analytical literature dealing with my period of interest.

Student newspapers were as valuable a source of information as interviews. Unlike in human memory, the ideas in them remained as detailed today as the day they appeared in print. Letters to the editor sections were particularly useful for providing a range of opinion while editorials, despite their biases, were useful for summarizing issues and providing analyses of key conflicts.

I retrieved the names of student leaders from NFCUS and CUS minutes. Many of these people were found in recent editions of "Canada's Who's Who." With this information I was able to easily locate them. During the interviews, I was usually able to find the whereabouts of other former leaders. NFCUS and early CUS executives and staff members all went on to prestigious careers in government, business, law, labour and higher education, the historical and social effects of which are beyond the immediate concern of this work. So the 
former student voices herein are those of people who have since attained a great deal of social status and insight into the Canadian state.

Space does not permit a full analysis of the interviews. I detected memory lapses and post-experience memory interference. Yet it was clear from the minimally directed, opening section of my interviews, that the three top issues that former student leaders felt passionate about were: (1) the lobby for accessibility, (2) international student politics and (3) simply keeping their organization alive. My interview data corroborate data I obtained in the student newspapers and NFCUS and CUS documents.

A full-scale account of all the actors whose agency led to a given policy is beyond the scope of this paper. Thus, I do not claim that either NFCUS or CUS or its provincial components were the sole agency in policy formation. Student leaders were taken seriously by some university administrators and politicians in various ways, at various times, and for various reasons. However, there was a widespread inability of many adults in positions of power to take student leaders seriously. Student organizations were far from the direct apparatuses of decision-making, yet their activities and political positions were responded to in calculated ways. While NFCUS and CUS alone did not achieve accessibility policy, undoubtedly they were key social agents, edging bureaucrats and university administrators on at every opportunity.

\section{THE NFCUS LOBBY FOR STUDENT-AID}

The NFCUS of the late 1940s and early 1950 s was not just a straightforward continuation of the rather conservative NFCUS of the 1930s (see Axelrod, 1989, for discussion of NFCUS in 1930s). In the late 1930s, it was the Canadian Student Assembly (CSA), founded in 1938, not the NFCUS that pursued a campaign to pressure the federal government to provide a thousand student bursaries worth $\$ 500$ each. So the post-war NFCUS was really an heir to the CSA and NFCUS of the 1930s. There is need for more historical documentation of NFCUS before and after the war, but it is clear that after re-establishing itself in 1947, NFCUS (1947) passed a resolution asking for "federal and provincial authorities to secure scholarships and bursaries for Canadian Students..." 
In 1950, on behalf of NFCUS, student leaders from the University of Montreal submitted briefs to the Royal Commission on National Development in the Arts, Letters and Sciences (the Massey Commission). NFCUS leaders deplored the condition of student funding and asked provincial and federal governments for a system of bursaries (Neatby 1992, 1993). The Commission recommended in its 1951 final report a "national system of scholarships which should be founded on adequate federal aid" (Martin, Hammond, \& Arthurs, 1958). But the recommendation was ignored. "It was 1950 before NFCUS became an "issue" [this was when] ideas of national scholarships were first really set in motion..." (Smyth, 1955). Certainly by 1954, if not earlier, NFCUS was making annual presentations to provincial and federal governments asking for student bursaries (Brewer, 1955).

Despite much effort by NFCUS leaders, no substantial government action on student-aid occurred until the Canada Student Loan Program (CSLP) in 1964. The Ontario government instituted only minor increases in student-aid throughout the 1950s and early 1960s (see Tables 1 and 2). Student-aid was a low priority for the Progressive Conservative federal government (1957-1963) and the Liberal government (1935-1957) before it, except for student veterans' assistance, the distant cousin of the CSLP. The Department of Veterans Affairs University Training Allowance was the most important government program to improve accessibility during and after the Second World War and the Korean War. In the 1949-50 academic year, for example, veterans made up $21 \%$ of university enrolment in Canada; in 1950-51, 11\%; in 1951-52, 7\% (Department of Veteran's Affairs, 1952, see also Moses, 1995). University calendars made the student-aid situation appear a lot better than it actually was, as they still do today. Countering this façade, post-war NFCUS leaders consistently pointed out that bursary disbursements were too small to encourage the "economically disadvantaged" to attend university. Financial aid to students before CSLP clearly played a key role for impoverished students. However, it is also clear that many bright students missed the opportunity of higher education or were hampered in their attempt to become educated because of their family's poor financial situation. 
Table 1

Total Scholarships and Bursaries Awarded Under Provincial and Dominion-Provincial student-aid Programs in Ontario, 1947-48 to $1965-66^{*}$

\begin{tabular}{lcccc}
\hline Year & Number & Amount & Av. Value & $\begin{array}{c}\text { \% of students } \\
\text { receiving aid }\end{array}$ \\
\hline $1947-48$ & 735 & $\$ 176,510$ & $\$ 240$ & 2.5 \\
$1949-50$ & 886 & $\$ 203,620$ & $\$ 229$ & 3.4 \\
$1951-52$ & 1,130 & $\$ 252,762$ & $\$ 223$ & 5.3 \\
$1953-54$ & 1,292 & $\$ 276,400$ & $\$ 213$ & 6.8 \\
$1955-56$ & 1,450 & $\$ 392,441$ & $\$ 270$ & 6.7 \\
$1957-58$ & 1,962 & $\$ 477,583$ & $\$ 243$ & 7.6 \\
$1959-60$ & 3,711 & $\$ 1,002,447$ & $\$ 270$ & 12.6 \\
$1960-61$ & 4,375 & $\$ 1,156,162$ & $\$ 264$ & 13.6 \\
$1961-62$ & 4,813 & $\$ 1,395,000$ & $\$ 289$ & 14.0 \\
$1962-63$ & 5,481 & $\$ 1,624,302$ & $\$ 296$ & 14.7 \\
$1963-64$ & 6,486 & $\$ 1,893,092$ & $\$ 291$ & 15.3 \\
$1964-65$ & 7,768 & $\$ 2,338,824$ & $\$ 301$ & \\
$1965-66$ & 8,883 & $\$ 2,809,177$ & $\$ 316$ & \\
\hline \multirow{5}{*}{ * From Cook and Stager (1969), except for "\% of students receiving aid" which is my } \\
own calculation. Note: these figures do not include CSLP (a student loan program) \\
disbursements.
\end{tabular}

Before the CSLP was introduced, the dollar amount of student-aid paid out to each recipient increased slightly each year, yet the average bursary a "needy" student received did not even cover the tuition fee! In the academic years between 1949-50 and 1958-59, annual increases in the number of students receiving aid was between $0 \%$ and $2 \%$, with a $5 \%$ leap in 1959 and an average of $1 \%$ annual increase after that (see Table 1). Vanderkamp (1984) showed that in Ontario, real student-aid per student (in 1971 dollars) ${ }^{3}$ went from $\$ 58(1951-52)$ to $\$ 60$ (1955-56) to $\$ 77$ (1959-60) to $\$ 124(1963-64)$ to $\$ 522$ (1967-68). Note that the biggest jump came between 1963-64 and 1967-68. This four fold increase, a significant jump, was due to CSLP and OSAP. 
Table 2

\section{Ontario Student-Aid Loans* (not CSLP or OSAP)}

\begin{tabular}{lccc}
\hline Year & Number & Av. Value & $\begin{array}{c}\text { \% of students } \\
\text { receiving aid }\end{array}$ \\
\hline $1959-60$ & 2,198 & $\$ 421$ & 7.5 \\
$1960-61$ & 3,361 & $\$ 413$ & 10.1 \\
$1961-62$ & 4,312 & $\$ 432$ & 12.0 \\
$1962-63$ & 5,249 & $\$ 444$ & 13.4 \\
$1963-64$ & 6,606 & $\$ 441$ & 14.9 \\
$1964-65$ & 289 & $\$ 396$ & 0.5 \\
& & \\
* From Cook and Stager (1969), except for "\% of students receiving aid" \\
Note: In 1964-65, the program was wound down and replaced with the Ontario \\
Scholarship and Bursary Assistance Fund and Canada Student Loan Program \\
\hline
\end{tabular}

NFCUS's campaign for aid was made difficult as governments were always making it appear that every student reform was a "momentous occasion." Hence, the most important aspect of "increases" to studentaid, both minor and major, was always the powerful ideological effect they had on predominantly "middle class" students, those fortunate enough to already be in university. So there was a tendency among the predominantly privileged students to take only a passive interest in NFCUS. For most students, student-aid was not a major issue, since it seemed that a lot of bursaries and loans were available for those less fortunate. NFCUS had many unofficial "members" then - those financially strapped working class youth that were unable to attend university.

The main tool NFCUS leaders used to communicate with university administrators, boards of governors, politicians and various commissions was the brief. Briefs were always based on policy resolutions passed at annual NFCUS congresses. After ratification by regionally representative executive members, briefs were distributed to local NFCUS committees, university administrators and politicians. Whenever possible, NFCUS leaders arranged meetings between themselves and university presidents, cabinet ministers and other politicians. NFCUS representatives met with the Prime Minister, usually on an annual basis. They always pressured 
for more and larger student bursaries (non-repayable student-aid). Briefs, becoming more sophisticated over time, were the most important tool for helping transform public opinion and government and political party policies.

In December 1954, NFCUS asked the federal government for a federal student-aid program costing $\$ 5.5$ million (UWO Gazette, 1955a). The federal Liberal government was not interested, citing problems of "constitutionality." This, I believe, conveniently masked other factors such as "free enterprise values" that meant students or their families would have to pay themselves (Axelrod, 1982). The Constitution did not prevent direct federal funding for postsecondary education, for example in the Appropriation Acts. Why, then, was "constitutionality" evoked when it came to transforming veterans' aid into a broad program of student-aid for everyone? By the early 1960s, the big business attitude toward accessibility became less strident and more liberal. Axelrod correctly argues that this change of position was less for moral social justice reasons and more due to concerns about economic development and having enough human capital (see Bladen, 1965 for a synopsis of big business attitudes). While NFCUS leaders were motivated mostly by social justice concerns, they also promoted human capital arguments for student-aid as part of their lobbying strategy, and, in fact, were constantly reminding business, university and political leaders of these arguments (see NFCUS 1958 brief, for example). Certainly by 1964, presidents of Canada's top two banks supported the proposed student loan act, even if it was for self-serving reasons. They "supported it enthusiastically as a means of strengthening their contacts with students" (Federal Government of Canada, 1964b).

A 1955 meeting between NFCUS leaders and members of the Ontario government (UWO Gazette, 1955a) and a 1957 "memorandum" submitted to the federal government and "political parties and other appropriate organizations at all levels" (UWO Gazette, 1957a) typify the sort of meetings and activities that happened over and over. They were part of NFCUS's ongoing student bursary campaign that slowly gained university administrator attention throughout the 1950s. According to former NFCUS staff executives (personal communication, 1992-93) 
much effort was spent on publicizing such meetings, which often gained nation-wide press, radio and television coverage.

In 1956, NFCUS submitted a brief to the Royal Commission on Canada's Economic Prospects (the Gordon Commission) (see Martin, Hammond, \& Arthurs, 1956). NFCUS's submission and verbal presentation to the Royal Commission was the quintessential beginning of the state's adoption (via the Liberal Party) of NFCUS's number-one demand: 10,000 bursaries. The Commission was chaired by a member of Canada's business elite, Walter Gordon who, according to his biographer Denis Smith (1973), was the Liberal Party's "miracle man," the "architect of the Liberal Party's reconstruction" (p. 9) after its 1957 and 1958 defeats. According to Newman (1968), Gordon, unlike many of the oldline Liberals and businessmen, did not believe the free market to be the most appropriate mechanism for allocating the nation's assets. Some even accused him of being a "traitor to his class."

Nothing appeared in the Commission's final reports that referred to NFCUS's brief and presentation. The official message to NFCUS was clear: if you were poor, you would have to find a job and pay your way through university (see Dubé, Howes \& McQueen, 1957). However, from the verbatim records taken during presentations to the Royal Commission, Gordon (p. 8205) was obviously impressed with NFCUS's proposal. He stated that it was an interesting submission and that they would undertake to think about it very seriously. That he thought about it seriously was evident here and later, when he became Finance Minister. In an address to a 1960 NFCUS seminar, Gordon (1977) stated:

we shall have to take much greater care to see that no really bright boy or girl is dissuaded from continuing his or her education after high school because of financial considerations.

(p. 349)

Gordon went on to become a major proponent of student-aid, helped draft the 1964 student loan legislation (see Toronto Star, 1963) and introduced it in the House of Commons.

The business-aligned Royal Commission on Canada's Economic Prospects was clearly not interested in bursaries, given that skilled labour could be imported, demand for university education would grow 
and that Canada's economic future would be buoyant (providing lots of summer and part-time jobs for "less economically fortunate"). Nevertheless, the Commission was certainly enthralled by the idea of the "buy now, pay later" approach, already proven to work in the housing and automobile industries. Yet NFCUS leaders' position on loans, as seen in the Commission hearings, was that loans were unnecessary given that educated people would earn greater incomes and would repay their debts to the government through higher income taxes.

\section{THE 1958 "BRIEF ON GOVERNMENT AID TO HIGHER EDUCATION"}

In 1958, NFCUS leaders produced and widely distributed their "Brief on Government Aid to Higher Education." This was NFCUS's most sophisticated brief thus far. Walter Tarnopolsky, ${ }^{5}$ (NFCUS Vice President 1955-57 and President 1957-58) stated:

we had a very good brief in 1958 . Glossy, that was really the start of the whole student bursary things. There was nothing before our brief. And we hammered and hammered every year. This was our main plank... Every year we came back to it [bursaries] regardless of what other things we did, that was always at the top of the agenda. (personal communication, 1992)

By that year, NFCUS had also developed better relations with university presidents and their national association. It had also played a "major organizing role" in the first Canadian Conference on Education that culminated in a plenary address by NFCUS President Water Tarnopolsky (Canadian Conference on Education Proceedings, 1958, pp. 94-99). NFCUS considerably expanded its staff, developed a popular "travel department," balanced its budget for the first time in years, and received widespread mass media coverage (former NFCUS leaders and staff, personal communication, 1992-93). Most important for the student-aid lobby, all student councils were back in the Federation following a mid1950s membership crisis.

NFCUS leaders used the state's education data to fortify their argument for greatly increasing student-aid. The 1958 brief made two main points: first, industrial and commercial development needed more university-trained personnel; second, financial barriers to education were 
unjust - the principle of "equality of opportunity" was central in the NFCUS program of action. The brief stated that only $5 \%$ of Canadians 18 to 24 years old were enrolled in university in 1956-57, compared with U.S. universities, in which $20.1 \%$ were enrolled. The brief emphasized the underdevelopment of the liberal arts and humanities and that youth from "low income groups" had a strong psychological aversion to taking loans and being in debt.

The 1958 brief also tackled constitutional issues, a topic of perennial sensitivity. Financially healthy federal tax coffers were the most likely source of NFCUS's proposed bursary plan, but federal funding for education was technically unconstitutional. On one hand, the authors of the brief pointed out that federal aid was already accepted in veterans and federal-provincial student-aid schemes, and that all that was needed was to "bring the scheme [student-aid] up to date." But on the other hand, the brief suggested changing federal-provincial taxation fields, the position promulgated by Quebec francophone NFCUS members. NFCUS lacked consensus on the technicalities of how student-aid should be funded. Nevertheless, the dominant position formed by the majority of the NFCUS membership (English-Canadian) was for federal aid - no matter what. This position eventually tore NFCUS apart.

For the Progressive Conservative (PC) federal government (1957-62), federal funding for student-aid was out of the question. Why was this? First, the Gordon Commission had not made any recommendations concerning student-aid. This relieved any pressure on the new federal government to act. Second, in the 1957 and 1958 federal elections, with support of Quebec Premier Maurice Duplessis's Union national, a large contingent of Quebec PCs was elected (Bothwell, Drummond \& English, 1981). Duplessis had refused federal funding for education from the time such funding was established in 1951 because he and his party viewed it as a federal incursion into a provincial jurisdiction. So any move to create a federally-funded student-aid program by the federal PCs would have been unpopular with the Union national and strained support for the PCs in Quebec. There is a third possible factor explaining PC inaction on student-aid. As did the old-line Liberals, the PC MPs did not feel that getting something for free was a good idea. Student-aid, 
especially bursaries, would have been contrary to their individualist and entrepreneurial values. The actual reasons for inaction on student-aid are not important here. What is important is how PC inaction on student-aid opened up a tremendous political opportunity opened up for the Liberal Party.

In December, 1962, on the eve of the PC government's 1963 electoral defeat, an ad hoc Cabinet committee was struck to discuss "possible plans for federal loans to university students and the type of announcement that might be made on the subject" (Federal Government of Canada, 1962a). It took the committee a mere five days to come up with the recommendation (subsequently ignored) that a " $\$ 10$ million loan fund be created" (Federal Government of Canada, 1962b). This would have meant an additional $\$ 1.5$ million per year to provincial loan programs that already were contributing $\$ 4.5$ million annually. The nonverbatim Cabinet minutes of December 18 mention that a majority of the PC Cabinet members believed that this "would not have a significant influence on university students." Spending money on building universities was considered more important or else "there would be no room for students." The ad hoc committee considered who would disburse the loans, eligibility criteria and how there should be "talks with the provinces and further consideration of the appropriate agency to administer the loans." Despite the committee's recommendation to make an announcement in the Commons for a $\$ 10$ million student loan fund, it is clear that the majority in Cabinet was against the idea - the announcement never came. The Cabinet minutes record discussion about how the fund would receive criticism from the Province of Quebec, which had been critical of the federal Liberal Party's proposed bursary plan. The majority opinion of Cabinet was that there was no urgency in proceeding with the proposal and that the need to provide these loans to students was not critical. The Cabinet minutes report that the ministers concluded their discussion by agreeing to discuss the matter of university student loans at another meeting. That meeting never came. My interpretation of the December 13 and 18 Cabinet meeting minutes was that the PCs were desperately attempting to come up with a means of gaining public support to take some of the wind out of the sails of the obviously popular 
Liberal student-aid proposals. Yet, evidently, there was still PC support for Quebec's position, which was strongly against federal involvement in student-aid.

Unrestricted by the constitutional and political concerns of the federal government, the PC Ontario government did respond to NFCUS pressure, but only in a token manner. In consideration of the publicity of NFCUS's campaigns, it was politically prudent for the provincial government to at least appear to be doing something. And besides, as discussed earlier, the attitude of business leaders and politicians was shifting toward support for student-aid. So in 1959, the Ontario government introduced Ontario Student-Aid Loans (see Table 2). That this program was announced in a provincial election year indicates that the government was worried about appearing uncaring toward popular (student-driven) concerns. NFCUS leaders were quick to criticize the tokenism of the program: it was more about shuffling pre-existing funding programs than about doing something substantial (The Varsity, $1959 \mathrm{~b}) .{ }^{6}$ Note that no changes occurred in federal contributions to student-aid between 1953 and 1964. Funding increases came only from provincial coffers. During this period, the federal government reimbursed the Ontario government for less than $10 \%$ of its total student-aid costs (Cook \& Stager 1969).

The Ontario government's student loan initiative was half-hearted and cosmetic. This was no doubt linked to politicians' recognition of growing "demand" while attempting to placate public concern aroused by NFCUS's campaign. Ontario Student-Aid Loans were repayable (that is, they were not bursaries); they were relatively small in size; and only a small number of students actually received them - approximately $7 \%$ to $15 \%$ of the student population between the academic years $1957-58$ and 1963-64 (see Table 2). While NFCUS leaders were able to penetrate the government's façade, their job of rousing the student body to demand more student-aid was made even more difficult because of what was essentially clever propaganda. The NFCUS lobby was co-opted by the Ontario government which offered a few repayable tidbits. Ontario Student-Aid Loans were certainly better than nothing. But this was hardly a student-aid program that would attract young, bright, working-class 
men and women into university, which was NFCUS's explicit intent. It is no wonder that a popular Marcusian analysis of co-optation by "the establishment" pervaded so quickly.

As student enrolment started to increase in the late 1950 s, so did NFCUS's budget and its ability to hire more staff. According to the one NFCUS insider, there was a "constant struggle to increase [NFCUS membership] fees" so that more staff could be hired. NFCUS staff provided continuity in an organization whose membership and leadership changed yearly. With more staff, NFCUS was better able to press governments for more student-aid; and later, by the mid-1960s, it provided the organizational basis for new left radicalism.

\section{THE LIBERAL PARTY ADOPTS NFCUS'S BURSARY PROPOSAL}

In December 1960, NFCUS representatives presented their case for a national bursary program directly to the Progressive Conservative federal government - this time to a special committee on education, struck to study the constitutional aspects of education (UWO Gazette, 1960). Not surprisingly, nothing happened. However, while the Conservative MPs listened politely, the Liberal Party, under the moral leadership of Walter Gordon and others, made NFCUS's bursary proposal part of their election platform - a strategic move. NFCUS was finally having some obvious success. Years of struggle, countless meetings and campaigns, speaking out and letter writing had, in part, created political conditions that politicians eventually could not ignore. Between the 1953 and 1962 elections, approximately 2,000,000 youth reached voting age (Leacy, 1983). The PCs tapped this growth with their mid-1950s model parliament movement (UWO Gazette, 1957b) and the involvement of students and youth in "Diefenmania" (see Meisel 1962, pp. 65, 75). But the Liberals soon caught on and, evidently, became better at harnessing youthful idealism. ${ }^{7}$ Walter Tarnopolsky (NFCUS President 1957-58) summarized the situation:

Year after year we weren't getting that much of a response [on the national bursary proposal]. In the end the student Liberals backed it, Liberal government in power, Liberal government 
gave it to them... Student opinion was not necessarily in sync with the rest of the country, remember that for most of my time, the PCs were in power [from 1957 to 1963] but I would say that the majority of us in the student movement were Liberals although there was a mixture [of party allegiances]. (personal communication, 1992)

A 1961 issue of the Liberal Party publication, the University Liberal (1961), states how the Canadian University Liberal Federation (CULF) was "Canada's largest and fastest growing student political movement" and how, if elected, the Liberal Party would establish

an extensive scheme of Canada Scholarships. This will be a major step in implementing the principle that education, at the university level, should be free to all those who can take advantage of it... The initial program will provide 10,000 awards each year, with a value of $\$ 1,000$ each. [emphasis mine]

By 1962, the Liberal Party's election platform had enshrined the above position. The Liberals also promised something in addition to a bursary program - a loan-based student-aid fund whereby:

All qualified university students will be able to borrow if necessary for genuine educational needs. The fund will be independently administered. Loans will be interest-free during the period of study and for the first year afterwards, and will then be repayable, plus interest, within a reasonable period. (Carrigan, 1968, p. 265).

In effect, the Liberal Party adopted NFCUS's student-aid policy. However, a key component of NFCUS policy was that aid be in the form of non-repayable bursaries. The bursary promise was broken when Canada Student Loan Program was established - a loan-only program. We can infer that the shift of student support to the Liberal Party between 1958 and 1964 was, in part, related to the Liberal Party's feigned enthusiasm for NFCUS policy (see Moses 1995, pp. 225-239). And further, among other things, that the broken promise to establish bursaries provided impetus for some student leaders to embrace a new left analysis of co-optation and the establishment. 


\section{NFCUS AND CUS AND THE ESTABLISHMENT OF THE CANADA STUDENT LOAN PROGRAM (CSLP) LEGISLATION}

In 1964, the student-funding situation changed substantially when the Liberal Party established the CSLP. ${ }^{8}$ CSLP was a major shift in government student-aid policy, unlike changes up to that point. I infer that the Liberals' promise of "free" university education made in 1961 was designed to be broken. Their real goal after the early 1960 s was a lowcost (to government) loan program. After the Liberals established the loans-only CSLP, there was still the chance that they might introduce the long-promised mass bursary program. Despite pressure from CUS and opposition parties, they never did.

The 1961 presentation to the federal Cabinet on National Student Day, February 19, was the last time NFCUS officially presented its case for federally-funded bursaries (see UWO Gazette, 1961, Jan. 27 and Feb. 17). While the lobby continued at the provincial level, the federal lobby was dead. NFCUS passed a resolution that officially ended the federal student-aid lobby. Around this time, according to former NFCUS Executive Secretary André L'Heureux (personal communication, 1993), indépendentiste feeling among francophone Quebec NFCUS members seemed to suddenly emerge, especially when it became apparent that the federal Liberals intended to increase direct funding of education. Quebec student leaders, like their provincial government, were uncomfortable with federal funding for education and lobbied for provincial studentaid. Quebec's policy was that education should remain under provincial and Catholic Church control (Neatby, 1993).

The 1958 NFCUS brief supported federal funding for the proposed bursary plan due to the federal government's relatively great financial power. However, reflecting Quebec NFCUS members concerns, the brief also stated the hope that leaders of both levels of government would find it possible to develop an adequate solution that respected the federal system, implying a need to change provincial-federal taxation fields. Quebec NFCUS members preferred education funding and student-aid under direct provincial responsibility and control (see UWO Gazette, 1960, Sept. 30) and outside the purview of the Catholic Church. NFCUS's new 
provincially-focused student-aid lobby seemed to appear suddenly, no doubt reflecting a key shift in Quebec's "quiet revolution." NFCUS shifted pressure for student bursaries from the federal level to the provincial level while calling for "...a new distribution of powers of taxation that will enable the provinces to meet their obligations in their respective fields of jurisdiction." This situation gave impetus to the formation of provincial organizations which from that point on had responsibility for the student-aid lobby.

\section{CSLP: STUDENT VICTORY OR BINATIONAL DISASTER?}

The NFCUS federal lobby was officially over, but that did not stop individual student councils and provincial components of NFCUS from independently lobbying for federal aid. This lobbying and lack of solidarity with Quebec's position considerably aggravated "binational" tensions within NFCUS and CUS. ${ }^{10}$ When the CSLP was legislated in 1964, the French-English conflict came to a head - francophone Quebec student councils withdrew from CUS and formed the UGEQ (Union général des étudiants du Québec). With NFCUS policy firmly incorporated into the Liberal Party election platform, the field of historical action shifted. The Liberal Party and its youth groups emerged as the champion of federally-assisted accessibility. NFCUS/CUS, as a national or federally-focused collective of student councils, had its hands tied by its new policy calling for a provincial focus in its lobby for student bursaries. No doubt the provincial focus would have been supported by the growing presence of PC-affiliated youth in NFCUS and CUS after 1959. Nevertheless, by the time NFCUS officially ceased its federal lobby, the ball was rolling for a federal student-aid plan.

The Liberal Party's adoption of NFCUS's policy in the early 1960s was the real point of "victory" for the NFCUS bursary lobby, perhaps more so than the actual passing of CSLP legislation in 1964. The NFCUS and CUS's official non-involvement in the federal student-aid lobby after 1961 was of little consequence for the now more generalized student and youth movement for federal student-aid. NFCUS and CUS students redoubled their lobby at the provincial level. Yet, as individual student councils and supporters of the federal Liberal Party, they did what they 
wanted, which was to lobby federally without concern for official proConstitution and pro-Quebec NFCUS and CUS policy. Within NFCUS, much was done to consolidate French-English relations, including renaming the organization in 1963. The new CUS structure contained a binational veto arrangement, but this veto power, along with a no-federal-lobby policy, was meaningless when individual student councils acted alone, without regard for NFCUS/CUS policy or Quebec's constitutional rights. The important thing to remember is that NFCUS/CUS's lobby on aid between 1961 and 1964 was not nearly as important to the establishment of the CSLP as its lobby between 1956 and 1961 whereupon the Liberal Party adopted, verbatim, NFCUS policy. This is not to say that the student lobby for bursaries was unimportant after 1961 . Despite organizational fragmentation, the lobby remained strong. Even the rise of PC youth involvement in NFCUS at this time did not hamper the lobby, as PC youth also supported mass student-aid.

\section{CUS IN THE HOUSE OF COMMONS}

That the student lobby was active, despite CUS's Standing Resolutions 10 and 11, was evident in the House of Commons debates. Mr. Ron Basford, MP, provided the most obvious evidence of extensive and unofficial CUS activity. He made the following statement:

This bill is assured, surely, of easy passage through this house. This easy passage has been assisted by the work of the officers of the CUS who, I think, have become familiar figures around Parliament Hill during the last few months in talking up the case for university loans... All I can say is that the students of Canada are well served by the officers of the CUS. (House of Commons Debates, July 15, 1964, p. 5524)

T.C. Douglas, leader of the New Democratic Party, provided further evidence of CUS influence. Douglas stated:

The Canadian union of university students [sic] has done a great deal of work on this matter [how students fund themselves to go to university]. (House of Commons Debates, July 15,1964, p. 5452) 
Douglas went on in the House to quote, at length, CUS President Patrick Kenniff as an authority on the subject of inequality of access. Douglas was clearly impressed with CUS and was among its most vocal allies. Student leaders' comments were sprinkled in the MP's debates in the House of Commons. ${ }^{11}$ Had it not been for CUS's official position against federal lobbying, I expect their "presence" would have been even greater.

I should emphasize that it was the Quebec university student councils, still official CUS members, who were quoted the most in the House of Commons debates over and above the unofficial CUS presence. Quebec student leaders, in fact, upholding official NFCUS and CUS policy, spoke against CSLP legislation, as did non-Liberal Quebec MPs. They spoke against federal student-aid because it undermined provincial jurisdiction over education, not because they disagreed with increased student-aid. Their position was to change the federal-provincial taxation fields so that the provinces could establish their own student-aid programs.

Just weeks before the loan act was to be legislated, Walter Gordon told Cabinet that he was "doubtful the scheme [the proposed student loan act] could be put into effect by the beginning of the next academic year" (Federal Government of Canada, 1964a). A few days later, Gordon made this statement in Cabinet:

The federal government might, following discussions with the provinces, [especially Quebec] have to accept an arrangement that was less attractive politically than that originally planned - whereby the federal funds involved would be turned over to the provinces and the latter would administer the program and would tend to receive all the credit. (Federal Government of Canada, 1964a, June 9)

A number of things can be deduced from this situation. First, the proposed legislation was even more complicated than imagined (Federal Government of Canada, 1964a, July 9). This would have related mainly to complex legal and constitutional matters. Second, Gordon was obviously concerned with the political effects legislation was going to have and did not want the provinces getting any credit. This is evident also in Gordon's concern for the wording of the proposed student-loan legislation - it would have to contain the word "Canada" and play down 
references to "the role of provincial authorities" (Federal Government of Canada, 1964a, July 11). In terms of my theoretical framework, Gordon's political concerns could be interpreted as a salient moment in the articulation of the state's hegemonic power. What better way was there to consolidate Liberal Party support (outside of Quebec at least) than by harnessing the movement for student-aid that NFCUS and CUS had so painstakingly built? The PCs unwillingness to act on NFCUS's lobby had cost them dearly. And the minority Liberal government, eager for a majority, was not going to waste any time in seizing the opportunity to respond to pent-up public support.

Immediately after the CSLP was established, there was a contradictory sense of victory and dismay among student leaders. Here is how CUS President David Jenkins responded:

Frankly, interest-free loans won't solve the problems facing Canada's students. What we would really like to see are bursaries (based upon need and marks)... However, if only loans and scholarships are possible at this time, we will gratefully accept them. (Cord Weekly, 1964a)

Grateful acceptance translated into a general disorientation, assisted by the departure of francophone Quebec student councils from CUS, the new concern with rising tuition fees and the process of forming stronger provincial wings of CUS.

I asked all the former student leaders if they thought the lobby for student-aid had been successful. I asked them if they thought there was a relationship between their lobby and student-aid programs. All of them saw a strong correlation. Although their responses are not indisputable proof of student organization influence, their opinions cannot be ignored. Walter Tarnopolsky (NFCUS President 1957-58) stated:

I think all these years of the federal government paying out these bursaries, the whole bursary/loan/grant program arose out of our rallying cry for 10,000 bursaries...I'm still convinced that this whole student loan and bursary program was a result of NFCUS's pushing year in and year out. I don't think there's any doubt about that. We played a major role in keeping student views before governments...They [AUCC] didn't start it [student bursary lobby]. I mean later we 
convinced them to participate, but it was all a NFCUS initiative. (personal communication, 1992)

Student leaders from the early to mid-1960s felt the same way, for example, Stewart Goodings (NFCUS President 1962-63) thought:

The CSLP was the federal government's response to the lobbying efforts that NFCUS was making. The government went for a loan program; we were suggesting a bursary program. NFCUS was not satisfied with the student loan program...the feeling of the student leadership was that CSLP had an effect on accessibility, but did not go as far as it should have. (personal communication, 1993)

Jean Bazin (CUS President 1964-65) stated:

All I can say, there was a pretty determined effort to do whatever [could] be done within the context of the meeting at the time, and the sophistication that we had, which was limited. But here we were trying. We were a pretty powerful force relative to that particular question [student-aid]. (personal communication, 1993)

Despite the Quebec and English Canada division and the grumbling of CUS supporters about the CSLP being far from the promised mass bursary program, after 1964 student-aid had never been so good (UWO Gazette, 1964). The CSL Act passed easily. The predicted cries of "unconstitutional" from conservative Quebec MPs and future student leaders of UGEQ - strange bedfellows indeed - were politically expendable, just as they were within NFCUS and CUS. The establishment of the CSLP, no doubt, confirmed Quebec youth's growing disillusionment with the Canadian state, the consequences of which are well known.

\section{NFCUS RELATIONS WITH UNIVERSITY ADMINISTRATORS}

From at least the mid-1950s it was common practice for members of the university presidents' National Conference of Canadian Universities (NCCU) to attend NFCUS conferences. From at least 1959 , it became standard practice for NFCUS delegates to attend the NCCU national conferences. Here NFCUS delegates politely presented their briefs for more student-aid and had an important influence on 
university president opinion. Paul Becker, a self-proclaimed "insider," who was involved in NFCUS between 1959 and 1963 in various staff and executive capacities stated:

One of my achievements at this time was to get the Association of Universities and Colleges of Canada [which the NCCU eventually became] to treat us as a standard agenda item... I used to go... Initially we were not taken seriously. We used to form alliances with particular university presidents and deans. The key thing we wanted was official status but we couldn't do anything. Perhaps it was our own inexperience or an inability to formulate our objectives clearly so that we would be taken seriously by a federation of university administrations. As we got better at it we got taken more seriously. We got more recognition with persistence and achievement... (personal communication, 1992)

Over time, NFCUS developed allies in the NCCU and the two organizations together pressured the federal government for university funding. However, university administrator relations with the national student organization were not always as congenial, ${ }^{12}$ and deteriorated rapidly after September 1964, when, following the establishment of the CSLP, most universities substantially hiked tuition fees. The relations of CUS and other student groups with university administrators reached an all-time low in the late 1960s and early 1970s over a range of issues, from university complicity in war-related research, to university governance, to daycare. When university administrators and national student organization leaders were on good terms, mainstream student support for the national student organization increased. The opposite was true too, when administrators withdrew support, the mass of mainstream students did the same. In other words, university administrator attitudes toward NFCUS and CUS had a structuring effect on how students viewed their own organizations and leaders. Similarly, when the Liberals favoured NFCUS policy on student-aid, this was an impetus for greater student involvement.

NFCUS's cozy relations with university administrators in the late 1950 s to early 1960s attracted the more conservative (small and large "c") students who had previously been unconvinced of NFCUS's value and effectiveness. The student councils, which tended to house the more 
conservative students, started getting more directly involved in NFCUS and especially in the politics of the local NFCUS Campus Committees which tended to house those more critical of the status quo. During the early 1960 s to the mid-1960s, PC-aligned youth gained influence in NFCUS/CUS - for example, most of the leaders were PC-affiliated at this time. With the federal Liberals in power, an uneasy alliance developed on campus among young NDPers and other left-wing elements, and the Tories and small "c" conservatives. When "red Tory" philosopher George Grant published his Lament for a Nation (1965), this enabled an improbable convergence between Conservative nationalism and the rise of new left anti-Americanism (see Christian, 1993; Kostash, 1980).

\section{THE STRUGGLE FOR BURSARIES AND FREE TUITION FEES AFTER 1964}

In the two years after the establishment of CSLP and before the establishment of the Ontario Student Assistance Plan (OSAP), leaders of CUS and its newly formed affiliate, ORCUS (Ontario Region CUS) continued lobbying for non-repayable student-aid. Chanting "Grants not loans" and after 1964, "Abolish tuition fees," ORCUS was one of the most important student organizations to emerge in Ontario (and Canada) especially after CSLP. ORCUS and CUS continued to pressure the provincial and federal governments for a 100\% bursary (grant) program while lobbying against the unprecedented tuition hikes that came in the wake of the CSLP (see Moses, 1995). ORCUS and CUS efforts elicited reponse in the form of the Ontario Scholarship and Bursary Assistance Fund established in 1964 and OSAP in 1966. In its first year, the scholarship and bursary fund provided $\$ 750,000$ to Ontario universities for distribution to students in financial need. The explicit intention of the fund was to offset the cost of higher tuition fees for those students in greatest need (White, 1965; see also Cook \& Stager 1969).

The Ontario Provincial government was also expecting a federal bursary program (Toronto Star, 1966) (13 $^{13}$ and when this did not materialize, it created this pre-OSAP, ad hoc scholarship and bursary fund with the expectation that a federal bursary program would be forthcoming. After 
giving up on the federal government's promise of "10,000 Canada Scholarships" (bursaries) and under continued CUS and ORCUS pressure, OSAP was established, replacing the ad hoc scholarship and bursary fund.

OSAP was an arrangement that combined federal loans $(60 \%)$ with Ontario bursaries $(40 \%)$. Loans came from the federal government and bursaries came from the Ontario provincial government. Bursaries were proving to be a valuable means of gaining political support from the youthful baby boomers (Ontario Legislative Assembly, 1966b). A "60:40" student-aid plan transformed the field of historical action once again. This is seen most obviously in CUS's shift of focus away from "universal accessibility" to "academocracy" (the democratization of university governance) and eventually to the temporary disbanding of the national student organization in 1969. Like CSLP and earlier token student-aid programs, OSAP limited the movement for student-aid and took the sting out of the radical left, especially those espousing Marxist-Leninism.

It is clear that CUS, or at least its provincial component, ORCUS, was highly influential. Compare the statements that Bill Davis, former Premier of Ontario and Education Minister, was making with those of former ORCUS and CUS President Hugh Armstrong. Ontario Premier Davis stated: "Some students are building up too great a burden of indebtedness while others may be reluctant to go into debt to the extent necessary to continue their education" (Ontario Legislative Assembly, 1966b). CUS President Hugh Armstrong stated, "Loans are not an acceptable form of student-aid... Loans are a deterrent rather than an incentive" (UWO Gazette, 1966a). Such links reinforce my claim that CUS was influencing the thought and actions of the top decision-makers. In the legislature debates leading to the establishment of OSAP, R.M. Nixon, Leader of the Opposition, stated:

Other important contributions to the information on university education were made by the Canadian union of students [sic] who speak clearly, intelligently and effectively for the young people directly concerned by the decisions of governments and the community with regard to postsecondary education. (Ontario Legislative Assembly, 1966c) 
Nixon used CUS's arguments, for example, that a more educated population would allow people to make more money and thus pay more taxes. Nixon also called for the abolition of tuition fees and the creation of a "real" student assistance program. In one case, during debate, Ontario MPs were shamed' into supporting those young adults who would be barred from university because of poor financial circumstances. A.B.R. Lawrence, M.P.P., referred to how "more than a handful" of those present in the Ontario Legislature had received veteran's assistance and for this reason should support student bursaries over student loans (Ontario Legislative Assembly, 1966c).

The OSAP announcement was made in April 1966 (Ontario Legislative Assembly, 1966a). "Things got very active in Ontario," according to Hugh Armstrong (personal communication, 1993). When ORCUS and CUS leaders heard the news that the federal and provincial governments were not going to establish a $100 \%$ bursary plan, they were disappointed. ${ }^{14}$ Like CSLP, the ideological effect of OSAP itself was rather ambiguous, angering some student leaders and mollifying others - the new flock of students were generally happy with the new studentaid situation, which had never been so good. The letdown over OSAP was not the only issue causing friction. At this time, there were many simultaneously converging social factors such as demographics (for example, massive growth in the 18-24 year old cohort, the increasing number of female and working-class students), the intensification of the Viet Nam War, a sudden jump in tuition fees and the development of youth-centred cultures and markets. Without doubt, CUS's and ORCUS's main position - the long-held raison d'être for student movements in Canada - had become state policy, more or less. This policy transformed the field of historical action of the late 1960s and has been an instrument of state regulation of student protest ever since.

Student leaders were unhappy that loans were still a significant part of OSAP. Premier Bill Davis quickly responded to student criticism by convening a student-faculty-university presidents committee (UWO Gazette, 1966c; see also Toronto Star, 1966). The formation of this committee was a significant historic event for CUS and ORCUS. This was the first time that students were allowed representation on such a 
high-profile, advisory committee. The youthful Bill Davis achieved respect and political support from many youth.

CUS and ORCUS never got their $100 \%$ bursary program, but they certainly had historicity. This is evident in the $40 \%$ bursary component of OSAP, a frozen tuition fee policy, representation on government committees and above all, a heightened level of accessibility. Bill Davis reflects on his experiences with CUS. He states:

I think there is a matter of assigning credit where credit is due. And to my mind, we must give a great deal of credit to our students for creating concern and focusing new attention on... what a university should be and the manner in which it should be organized and operated... It is essential, therefore, that we take the time and make the effort to stand back and really look at ourselves and the kind of education that we are offering and decide whether it matches up to the needs of our society. And this, I would assert, is certainly one issue of which our students have encouraged us to take note.

Student unrest or the movement toward student power is, without question, the subject of great public attention. Thus it would be unrealistic, indeed impossible, to conduct any debate on university affairs in the current era without giving some attention to this very important aspect of higher education. (Ontario Legislative Assembly, 1968)

From my analysis of student newspapers, it is clear that there was widespread indignation on most campuses about the raising of fees, which happened soon after CSLP was implemented. ${ }^{15}$ Unlike studentaid, tuition fee hikes affected all students directly and at the same time. And CUS, whose membership was growing rapidly and becoming more inclusive and politically astute, was able to provide national and provincial form to a widespread "free tuition" movement. An early "radical" movement was to coalesce within CUS that was based on local protests against tuition fees.

Once CSLP was established, university administrators had the political space to raise tuition fees, and they did not hesitate. With many loans and bursaries to offer students, university administrators could raise tuition fees (a source of private funds) with less risk of criticism, or so 
they thought. In the mid-1960s, before the Fiscal Arrangements Act of 1967, the universities alone controlled tuition fee levels. It appears that raising tuition fees was the administrators' plan all along. The best evidence for this is found in the final report of the university presidents' Commission on University Finance (1965) (the "Bladen Commission"). The report contained a key recommendation for higher tuition fees and more student loans and bursaries.

There was already a small new left "radical" campus movement, the Student Union for Peace Action (SUPA), which had evolved from the Combined Universities Campaign for Nuclear Disarmament (CUCND) (see Kostash, 1980). In 1964-65, SUPA activism was still on the fringes of mainstream student council and CUS politics, but this would change rapidly. During the mid-1960s, many ORCUS and CUS leaders such as Hugh Armstrong became receptive to SUPA's ideas, for example, its anti-war position, critique of liberalism and style of protest. As well, some SUPA affiliates, recognizing a new critical impulse within mainstream student politics, became involved with CUS. Laxer (1969) remarks that by the 1968-69 academic year, the "staff and intellectual apparatus" of the formerly mainstream CUS contained many former SUPA activists. It is interesting to note how new left development in national student organizations in Canada and the U.S. were quite different. Similar to the Canadian situation, the national student organization in the U.S., the United States National Student Organization (USNSA) provided an organizational network for the development of the new left Students for a Democratic Society (SDS) (see Johnson, 1998; Sale, 1973). However, in the U.S., the SDS developed as a separate new left organization, while in Canada, CUS (the rough equivalent of USNSA) became new left, while maintaining, unlike the SDS, its basis of organization and representation in local student councils.

With unexpected and widespread student anger over higher fees and a new Black civil rights style of student activism related to SUPA, concerned federal and provincial governments agreed to provide more education funding. By 1966, adequate government funding released universities from their intention to raise their fees and, at the same time, quelled student indignation and mobilization. The Ontario Scholarship 
and Bursary Assistance Fund of 1964, discussed earlier, was a political opportunity that could not be missed. It also capitalized on the broad popularity of student-aid and the failure of the federal government to bring in its promised national bursary program.

In 1967, a stable and "regulated" tuition fee was established under the Federal-Provincial Fiscal Arrangements Act (Stager 1989). The federal government was happy to tie tuition fee levels to its grants to the universities, as it looked like CSLP would become a "cash cow" for university funding via student tuition fees. No doubt university administrators, who were attentive to the student protests south of the border, were relieved that they did not have to face angry students complaining about the threats to accessibility and demanding that fees be completely abolished. Although the CUS-coordinated anti-fees movements were coopted, they did achieve a frozen-fee policy that increased access to postsecondary education in the late 1960s.

Former University of Toronto President Claude Bissell provides some clues as to how university administrators and politicians managed campus dissent. Bissell (1974) reasoned: "The key was...to keep the traditional radicals from coalescing with the revolutionaries" (p. 138). The radicals were "in the main academic tradition of protest and dissent, now organized more carefully, far less respectful than their predecessors" while the revolutionaries "saw themselves as part of a worldwide ferment, and 'Columbia today, Toronto tomorrow,' was a battle cry in a campaign to overthrow the world establishment. What I must do was to enlist the radicals in the process of reform... to give them an active role..." (p. 129). By giving in to the "radical" anti-fees and bursary movements, by enlisting and giving students an active role, such as Premier Davis was doing, the "revolutionaries," in fact an assortment of conflicting groups and political persuasions, were systemically isolated and neutralized.

Following various announcements and promises of no more fee increases, the anti-fees issue on campus and within CUS dissipated as quickly as it had appeared. And like student-aid in general, the tuition fee freeze took away a potential catalyst for revolutionary movements that saw the university as part of the establishment to be overthrown. Tuition 
fees were not a major concern for CUS in late 1960s as they were in the mid-1960s. University administrator and federal and provincial government initiative to control and stabilize tuition fees in the mid-1960s was not just a socially-isolated, bureaucratic procedure as Stager (1989) suggests. Tuition fees were frozen as a direct result of student council and CUS protest. University administrators were startled and worried by the development of social movements among their students: anti-war, antiracist, anti-capitalist movements and, by the late $1960 \mathrm{~s}$, feminism. It is no coincidence that tuition fees remained stable throughout the most radical period of Canadian student organization history (1965-1972).

\section{CONCLUSION}

Accessibility policy should not be seen as just co-optation in the zero-sum Marcusian sense. Late 1960s and early 1970s anti-capitalist dissent was demobilized and neutralized by liberal-minded university administrators and politicians who removed traditional student movement catalysts. Yet access to universities and colleges in the late 1960s and early 1970s also ended up playing a key role in the growth of the new social movements. So-called "co-optation" was relative and, in fact, multidimensional. In many respects, the new policy environment of loans, bursaries and frozen tuition fees enabled social movements as much as it restrained them. Unbeknownst to them, student organizations of the 1950s to mid-1960s helped open up certain cultural and political spaces that gave rise to new identities in new social movements of the post-1967 period. This social condition was hardly the one-dimensional society that Marcuse warned students of in 1964. Moreover, student activism was less a factor of baby-boom demographics and more a factor of social actors responding to unjust and undemocratic class- and-generation-related social relations.

There was always an ongoing campus debate about the national student organization's "value to students" and "effectiveness." NFCUS and CUS presidents had to constantly inform students of the merits of collective action within a national student organization. This merit related not just to the organization's bursary lobby but to many other areas that 
NFCUS/CUS concerned itself with, such as its involvement in the International Union of Students or student services. Oftentimes the NFCUS president was "fighting brush fires," such as when uninformed student council treasurers wondered why they should pay membership dues to an "outside" organization, when there were pressing needs at home, like bigger floats for the next homecoming parade. Student council membership was constantly turning over. This meant NFCUS activists had to continually educate the membership and justify the worthiness of NFCUS. So in relation to this long debate as to NFCUS and CUS "value to students" and "effectiveness," this paper has finally set the record straight.

Did NFCUS and CUS make a difference? Clearly they did. Student agency mattered. This fact should inspire future generations of young people. Within the perspective of a revised concept of co-optation that I call mutual determination or simply co-optation, one can see how social actors in marginal locations, although far away from actual decisionmaking, can still influence state policy and ipso facto the very conditions of future social movements. Hence, it is appropriate to say that student organizations had historicity. Or, in other words, they helped establish certain government policies that reflected their cultural orientations, values and class-related interests. Through their persistent efforts, NFCUS and CUS activists had a long lasting democratic effect on the social relations of the university and society. In short, NFCUS and CUS helped shape the course of Canadian history.

\section{Notes}

1 Meaning "in place of parents" - rules and customs that gave university administrators the same rights as parents to dictate behaviour, especially in matters of moral regulation of student sexuality (for example, residence curfews).

2 For example, the average bursary given to each recipient in 1961-62 was $\$ 289$ (see Table 1), while the average tuition fee at this time was $\$ 413$ (based on averaging the tuition fees of the universities of Toronto, Waterloo, 
Waterloo Lutheran and York. Taken from university course calendars, 1961-62 academic year.

3 Defined here as including the federal and provincial contribution of scholarships and aid to students attending postsecondary education and the cost of making loans to students (not the actual amount of loans). This includes interest payments, default and service charges.

4 NFCUS asked Ontario Premier Frost directly for an additional $\$ 1.5$ million for provincial and dominion-provincial student-aid programs, which would have almost quadrupled the student-aid budged.

5 Honourable Mr. Justice Tarnopolsky, author of The Canadian Bill of Rights (1966), appointed Judge of the Court of Appeal for Ontario, 1983.

6 See also The Varsity, 1959a and UWO Gazette, 1959b which provide details of NFCUS Executive Secretary André L'Heureux's letter regarding the cuts.

7 For example, by the 1963-64 academic year, there were 17 "minority governments," 14 Liberal, 2 PC and 1 NDP (see Cord Weekly, 1964b). Yearly model parliaments were much more important campus events than they are today (see Moses, 1995, pp. 225-239).

8 The CSLP bill passed 137 to 14. Six PCs and eight Créditistes opposed because federal aid to education was unconstitutional (Gordon, 1977).

9 See NFCUS resolutions 67/NA/61 and 71/NA/61 in NFCUS resolutions (1961), which were reaffirmed and carried as standing resolutions 10 and 11 at the 1962 NFCUS Congress, NFCUS resolutions (1962).

10 Please recall that NFCUS became CUS in 1963. So by the time of CSLP legislation in 1964, we must refer to "CUS." Adding to the confusion is that fact that francophone Quebec members withdrew from CUS in 1964, not from NFCUS which had changed its name the year before.

11 See, for example, University of Toronto's Student Administrative Council President John Roberts quoted July 21, 1964; CUS President David Jenkins quoted July 15, 1964, House of Commons Debates.

12 See, for example, The Varsity, January 21 and 24, 1955 and "The President Speaks..." (extracts from a University of Toronto President's report) in The Varsity, January 31, 1955, p. 4.

13 See also Davis' comments in the Ontario Legislature, June 20, 1966. 
14 See the Toronto Star, September 25, 28, and 29, 1966. See also the UWO Gazette, (1966a, 1966b); Cord Weekly, (1966).

15 See, for example, UWO Gazette (1965); Cord Weekly (1965); Lambda (1965). See also Policy Declaration/4/64, CUS Resolutions, (1964).

\section{References}

Altbach, P. (Ed.). (1981). From revolution to apathy: American student activism in the 1970s. New Jersey: Scarecrow Press Inc.

Anisef, P. (1985). Accessibility to postsecondary education in Canada: A review of the literature. Ottawa, ON: Education Support Branch, Department of the Secretary of State of Canada.

Armstrong, H. (1993). Personal communication.

Axelrod, P. (1982). Scholars and dollars: Politics, economics and the universities of Ontario 1945-1980. Toronto, ON: University of Toronto Press.

Axelrod, P. (1989). Student movement of the 1930s. In P. Axelrod \& J.G. Reid (Eds.), Youth, university and Canadian society. Montreal, QC: McGillQueen's University Press.

Barkans, J., \& Pupo, N. (1978). Canadian universities and the economic order. In R.W. Nelsen \& D.A. Nock (Eds.), Reading, writing, and riches: Education and the socio-economics order. Kitchener, ON: Between the Lines.

Bazin, J. (1993). Personal communication.

Becker, P. (1992). Personal communication.

Bissell, C. (1974). Halfway up Parnassus: A personal account of the University of Toronto, 1932-1971. Toronto, ON: University of Toronto Press.

Bladen, V. (1965). Financing higher education in Canada. A Commission of the Association of Universities and Colleges of Canada.

Bothwell, R., Drummond, I., \& English, J. (1981). Canada since 1945: Power, politics and provincialism (revised ed.). Toronto ON: University of Toronto Press.

Bowles, S., \& Gintis, H. (1976). Schooling in capitalist America. New York, NY: Basic Books.

Breines, P. (1970). From guru to spectre: Marcuse and the implosion of the movement. In P. Breines (Ed.), Critical interruptions. New York, NY: Herder and Herder. 
Breines, P. (1971). Marcuse and the new left. In G. Fischer (Ed.), The revival of American socialism. New York, NY: Oxford University Press.

Breines, W. (1982). Community and organization in the new left: 1962-1968, the great refusal. South Hadley, MA: Praeger.

Brewer, B. (1955). News Roundup 1954. UWO Gazette, January 14.

Brint, S., \& Karabel, J. (1989). The diverted dream: Community colleges and the promise of educational opportunity in America, 1900-1985. New York, NY: Oxford University Press.

Canadian Conference on Education. (1958). Addresses and proceedings. G.G. Croskery \& G. Nason (Eds.), Ottawa, ON: Mutual Press.

Carrigan, D.O. (1968). Canadian party platforms, 1867-1968. Toronto, ON: Copp Clark Publishing Company.

Christian, W. (1993). George Grant, a biography. Toronto, ON: University of Toronto Press.

Churchill, W., \& Vanderwall, J. (1990). The COINTELPRO papers: Documents from the FBI's secret wars against dissents in the United States. Boston, MA: South End Press.

Cohen, S. (1972). Moral panics and folk devils. London: MacGibon and Kee.

Cook, G., \& Stager, D. (1969). Student financial assistance programs. Toronto, ON: Institute for Policy Analysis, University of Toronto.

Cord Weekly: (1964a). Federal money for students. March 20, p. 1.

Cord Weekly. (1964b). Model parliament wrap-up. March 20.

Cord Weekly. (1965). CUS Day October $27^{\text {th }}$. October 8.

Cord Weekly. (1966). Federal loan plan draws mixed reactions. November 25.

Daly, M. (1970). The Revolution Game: The short, unhappy life of the company of young Canadians. Toronto, ON: New Press.

Department of Veteran's Affairs. (1952). Annual report. Ottawa, ON: Department of Veteran's Affairs.

Dubé, Y., Howes, J.E., \& McQueen, D.C. (1957). Skilled and professional manpower in Canada, 1945-1955. Report to the Royal Commission on Canadian Economic Prospects, Economics and Research. Ottawa, ON: Department of Labour, p. 85.

Ehrenreich, B., \& Ehrenreich, J. (1977). The new left. Radical America, (2) 3, 7-22.

Ehrenreich, B., \& Ehrenreich, J. (1978). The professional-managerial class. In P. Walker (Ed.), Between labour and capital. Montreal, QC: Black Rose.

Federal Government of Canada. (1962a). Cabinet minutes, December 13. Ottawa, ON: National Archives, RG2, A5a, vol. 6193. 
Federal Government of Canada. (1962b). Cabinet minutes, December 18. Ottawa, ON: National Archives, RG2, A5a, vol. 6193.

Federal Government of Canada. (1964a). Cabinet minutes, June 4. Ottawa, ON: National Archives, RG2, A5a, vol. 6265.

Federal Government of Canada. (1964b). Cabinet minutes, July 11, Report by minister Walter Gordon. Ottawa, ON: National Archives, RG2, A5a, vol. 6265 .

Finkel, A. (1977). Origins of the welfare state in Canada. In L. Panitch (Ed.), The Canadian state: Political economy and political power. Toronto, ON: University of Toronto Press.

Foot, D., \& Stoffman, D. (1996). Boom, bust and echo. Toronto, ON: Macfarlane, Walter and Ross.

Gérin, J. (1992). Personal communication.

Gitlin, T. (1980). The whole world is watching. Berkeley, CA: University of California Press.

Goldson, B. (1997). 'Childhood': An introduction to historical and theoretical analyses. In P. Scraton (Ed.), 'Childhood' in 'Crisis. 'London: UCL Press.

Goodings, S. (1993). Personal communication.

Gordon, W. (1977). Whither Canada - Satellite or independent nation: Remarks to the national seminar. NFCUS at the University of British Columbia, August 29, 1960. In A Political Memoir. Toronto, ON: McClelland and Stewart.

Granatstein, J.L. (1986). Canada 1957-1967: The years of uncertainty and innovation. Toronto, ON: McClelland and Stewart.

Grant, G. (1965). Lament for a nation. Toronto, ON: McClelland and Stewart.

Guest, D. (1980). The emergence of social security in Canada. Vancouver, BC: University of British Columbia Press.

Harding, J. (1969). What's happening at Simon Fraser University. Our Generation, 6(3).

James, A., \& Prout, A. (1997). Constructing and reconstructing childhood. London: Falmer Press.

Jessop, B. (1982). The capitalist state. Oxford: Martin Roberson.

Johnson, A. (1998). Student activism in the United States before 1960: An overview. In G.J. DeGroot (Ed.), Student protest: The sixties and after. New York, NY: Longman.

Kostash, M. (1980). Long way from home: The story of the sixties generation in Canada. Toronto, ON: J. Lorimer and Company.

Lambda. (1965). CUS driving for free tuition. October 25. 
Laxer, J. (1969). The student movement and Canadian independence. Canadian Dimension, 6(3).

Leacy, F.H. (Ed.). (1983). Historical statistic of Canada (2nd edition).

Levitt, C. (1984). Children of privilege, student revolt in the sixties: A study of student movements in Canada, the United States, and West Germany. Toronto, ON: University of Toronto Press.

Marcuse, H. (1964). One-dimensional man: Studies in the ideology of advanced industrial society. Boston, MA: Beacon Press.

Marcuse, H. (1965). Repressive tolerance. In A critique of pure tolerance. Boston, MA: Beacon Press.

Martin, P., Hammond, T., \& Arthurs, H. (1956). Exhibit 235. Hearings (40-41), p. 8188.

Martin, P., Hammond, T., \& Arthurs, H. (1958). A brief on government aid to higher education. Ottawa, ON: NFCUS.

Moses, N.R. (1995). All that was left: Student struggle for mass student-aid and the abolition of tuition fees in Ontario, 1946 to 1975. Unpublished doctoral dissertation. Toronto, ON: Ontario Institute for Studies in Education, University of Toronto.

National Federation of Canadian University Students. (1947). Resolutions. Ottawa, ON: NFCUS.

National Federation of Canadian University Students. (1958). A brief on government aid to higher education. Ottawa, ON: NFCUS.

Neatby, N. (1992). L'évolution des attitudes et des activites des leaders étudiants de l'Université de Montréal de 1950 à 1958. Unpublished doctoral dissertation. Montréal, QC: University of Montréal.

Neatby, N. (1993). Student leaders at the University of Montreal from 1950 to 1958: Beyond the "Carabin Persona." Unpublished paper.

Newman, P.C. (1968). The distemper of our times: Canadian politics in transition, 1963-1968. Toronto, ON: McClelland and Stewart Limited.

Ontario Legislative Assembly. (1966a). Debates and Proceedings. April 4, pp. 2187-2188.

Ontario Legislative Assembly. (1966b). Debates and Proceedings. June 16, p. 4859.

Ontario Legislative Assembly. (1966c). Debates and Proceedings. June 20, p. 4897.

Ontario Legislative Assembly. (1968). Debates and Proceedings. June 10, p. 4170 . 
Owram, D. (1996). Born at the right time: A history of the baby boom generation. Toronto, ON: University of Toronto Press.

Poulantzas, N. (1978). State, power, socialism. London: New Left Books.

Report of the Royal Commission on National Development in the Arts, Letters and Sciences. (1951). Ottawa, ON: King's Printer (The Massey Commission).

Royal Commission on Canada's Economic Prospects. (1957). Final report. Walter L. Gordon, Chairman.

Sale, K. (1973) SDS. New York, NY: Random House.

Sheffield, E.F. (1955). Canadian university and college enrolment projected to 1965. Proceedings, National Conference of Canadian Universities, 39-46.

Shor, I. (1986). Culture wars, school and society in the conservative restoration, 1969-1984. Boston, MA: Routledge and Kegan Paul.

Smith, D. (1973). Gentle patriot: A political biography of Walter Gordon. Edmonton, AB: Hurtig Publishers.

Smyth, B. (1955). Pros and Cons of NFCUS ideals and achievements. The Varsity, January 19, p. 2.

Stager, D. (1989). Focus on fees: Alternative policies for university tuition fees. Toronto, ON: Council of Ontario Universities.

Stern, S. (1967, March). A short account of international student politics and the cold war with particular reference to the NSA, CIA, etc. Ramparts, 29-39.

Tarnopolsky, W. (1992). Personal communication.

The Varsity. (1959a). Bursary values down for some. January 6, p. 4.

The Varsity. (1959b). NFCUS unhappy. January 13, p. 4.

Toronto Star. (1963, May 1).

Toronto Star. (1966, September 28).

Touraine, A. (1988). Return of the actor: Social theory in postindustrial society. Myrna Godzich (Trans.). Minneapolis, MN: University of Minnesota Press.

Touraine, Alain (1995). Critique of modernity. David Macey, (Trans.). Cambridge: Blackwell.

University Liberal. (1961). Volume 1, Number 3. February-March. Ottawa, ON.

UWO Gazette (1955a). Province interested in aid for students. January 28, p. 3.

UWO Gazette. (1955b). This is how NFCUS works. December 2, p. 6.

UWO Gazette. (1957a). NFCUS asks governments to increase student-aid. January 11, p. 1.

UWO Gazette. (1957b). Conservatives, the students' party. January I1, p. 9. 
UWO Gazette. (1959). Money and 'U'. January 16.

UWO Gazette. (1960). Increasing costs place deterrent on education. December 9.

UWO Gazette. (1964). Students join the installment age: Ottawa's pay later education plan. September 25, p. 5.

UWO Gazette. (1965). Fee increases current problem across Canada. January 22.

UWO Gazette. (1966a). Protest aid program. September 23.

UWO Gazette. (1966b). 2000 march at U of T. September 30.

UWO Gazette. (1966c). SAP-Davis' first political slip. October 14.

White, P. (1965). Comment. UWO Gazette, January 29, p. 2.

Winsor, H. (1958). AMS (Alma Mater Society or student council) reverses policy on NFCUS: Four-hour meeting questions National President Bistrisky. Queen's Journal, November 21, p. 1.

Vandercamp, J. (1984). University enrolment in Canada 1951-83 and beyond. Canadian Journal of Higher Education, 14(2). 